\title{
Shorinji kempo basic technique training method based on local wisdom for beginners kenshi
}

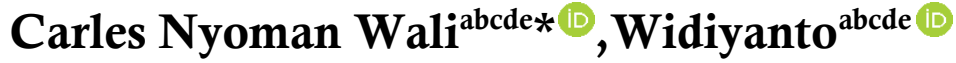

\begin{abstract}
Received: 12 February 2021; Accepted 18 July 2021; Published 17 December 2021
\end{abstract} Ed 2021; 6(3): 421-432

\begin{abstract}
The lack of training models and training creativity in creating traditional game-based training models for kenshi to improve the basic techniques of kempo becomes problems in this study. The purpose of this research is to produce a model of basic martial arts techniques of kempo through traditional games for kenshi beginners. This research is a research and development (R\&D) research which was adapted into 8 steps in research: 1). Field news collection 2). Breakdown of the news that has been collected 3). Elaborating initial creation 4). Expert validation and revision 5). Small scale trial 6). Large-scale trial 7). Making the final product 8). Product effectiveness test. The small-scale trial subjects of 20 beginners kenshi were taken from 2 dojos, namely the Panjatan Junior High School dojo and the Amikom dojo. The large-scale test subjects totaling 45 beginners kenshi were taken from 3 dojos, namely Balong, Triharjo, and SD Gunung Kidul. The subjects in this study came from 5 dojos in Perkemi DIY. Data were collected through interviews, distributing questionnaires, field notes, evaluation, and assessment rubrics for beginner kenshi. The results of this study are in the form of training models for basic techniques of kempo martial arts through traditional games for beginner kenshi, and there are five training models: 1 . gobak sodor, 2. yeye, 3. pahtil catfish, 4. zogdag, 5. stick dance. Based on the results of this study, it can be concluded that the traditional game-based kempo martial arts training model for kenshi beginners is feasible to use. The author's recommendation to other prospective researchers is to examine traditional games in an approach with other disciplines and use professional research subjects in other sports.
\end{abstract}

Keywords: Shorinji kempo; training; local wisdom; kenshi

https://doi.org/10.25299/sportarea. 2021.vol6(3).6403
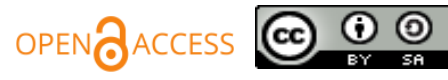

Copyright (C) 2021 Carles Nyoman Wali,Widiyanto

Corresponding author: Carles Nyoman Wali, Doctoral Department of Sports Science, Faculty of Sports Science, Universitas Negeri Yogyakarta, Yogyakarta, Indonesia

Email: carleswali@yahoo.com

How to Cite: Wali, C. N., \& Widiyanto. (2021). Shorinji kempo basic technique training method based on local wisdom for beginners kenshi. Journal Sport Area, 6(3), 421-432. https://doi.org/10.25299/sportarea. 2021.vol6(3).6403

Authors' Contribution: a - Study Design; b - Data Collection; c - Statistical Analysis; d - Manuscript Preparation; e - Funds Collection

\section{INTRODUCTION}

In the modern era, the crime rate continues to increase against children, so the attention and care of parents must be increased to prevent violence against children, especially elementary school children (Fonagy et al., 2018; Stark \& Landis, 2016). A very appropriate step for the safety of the baby is to encourage children to participate in extracurricular activities (Bartkus et al., 2012). Extracurricular activities provide benefits for children, in growth and development, health, and achievements that will be obtained by children. Extracurricular is an internal part of the learning process that emphasizes meeting the needs of students, the role of extracurricular activities is an extension or reinforcement of intracurricular activities to channel the talents and interests found in children's participants to increase the potential development of students to reach the maximum level (Brandão \& Lordelo, 2017; Guest, 2018). Shorinji kempo martial arts 
is part of extracurricular activities among children from elementary school to college level (Ricci et al., 2020). Each martial sport has a variety of basic techniques and various methods to be implemented in kenshi, in Indonesia itself has a variety of martial arts that can be followed by children such as Aikido, Judo, PSHT, Kera Sakti, Karateka, Inkai, Kempo and others (Downey, 2014; Petri et al., 2019).

The prevalence of crimes against children, so that self-defense becomes an important component to learn, so that when someone gets an attack from another person, that person is able to defend himself against the enemy (Züst et al., 2012). Self-defense must be carried out spontaneously and through concepts that are applied systematically, through games and sports (Xu et al., 2020). Because sports and games can help children or kenzhi in character building (Finnegan \& Accardo, 2018). Efforts to improve basic self-defense techniques, especially kempo martial arts, need a method to realize the goal of increasing the ability of kenshi to master various basic techniques in shorinji kempo martial arts (Liang et al., 2019). The basic techniques in martial arts are not easy to master but it must take a long time for someone to master every technique in self-defense, including the basic techniques of shorinji kempo martial arts (Samuel \& Johnston, 2013).

This happens because the mechanism of the training pattern is programmed, so the kenzhi are required to follow the mechanism that applies in the martial arts (Bowman, 2017; Wetzler, 2015). Through martial arts, students can improve three aspects, namely psychomotor, cognitive, and affective. For example, the psychomotor aspect will apply hitting, kicking, parrying, dropping, slamming, and locking movements. Therefore, martial arts are synonymous with hard, but martial arts can improve a person's physical health and provide true mental leadership. So that in training an athlete requires stages that need to be studied well (Cynarski et al., 2018). This applies to all martial arts and other martial arts, one of which is shorinji kempo martial arts (Kim et al., 2019).

Kempo martial arts was initiated in 1947 in Japan (So, 1981). The creator of the shorinji kempo martial arts is the 28th Buddhist priest Dharma Taishi (Misaki, 2013). In 550 the Buddhist priest left the city of Baramon/India for China (Shufelt, 2011). Kempo martial arts is an understanding that uses Japanese, while the name kempo martial arts comes from the Chinese state as Quanfa/chuenfa (Hanif, 2016). Universally, Shorinji Kempo is an imitation of the original Chinese martial art, Shoulin Kung Fu (Lorge, 2011; Park \& Kim, 2016). Then specifically, shorinji kempo martial arts can be interpreted as: small sho, jungle rin, ji temple ken fist, po one's way of life (Bowman, 2021; Irwan \& Mulyadi, 2017; Long, 2012).

Kempo martial arts is a martial art that has a variety of basic skills, such as kick, punch, parry, evasion, slamming. and locking techniques (Yates, 2015). A kenshi wants to excel, it is obligatory for the kenshi to master several 4 factors, namely: 1). Training in the formation of basic techniques of kempo self-defense systematically, 2). Maximum and structured physical exercise program, 3). Mastering training methods through traditional games, 4). Mental training competes well mentally (Scheunemann, 2012). So that in learning the basic techniques of shorinji kempo martial arts, trainers or hoops must know every characteristic of beginner kenzhi (Kamarudin, 2014; Wali, \& Widiyanto, 2020). Then the techniques that are applied or taught to the beginner kenzhi must be ensured that the beginner kenzhi understands each of these techniques. Because kenzhi is not really deep in basic techniques, it will be difficult to learn advanced basic techniques. For example, if a beginner kenzhi has not mastered the punching technique correctly, the kenzhi will experience problems when counter attacking the opponent. Therefore, it is not justified for a kenzhi to only understand one technique in kempo martial arts (James et al., 2017; Petri et al, 2019).

The main problem in this study is the emergence of various complaints and boredom experienced by beginner kenzhi. In general, the problem in this study is an authoritarian and monotonous exercise model, thus creating a rigid and boring exercise, so it is necessary for a coach to apply a game model during training. There is an acknowledgment that there is no training model that focuses on early childhood or kohai. Because the training model that has been used by the trainers is general in nature. The game-based training model applied by the trainers is required to know the function of the game, so that it does not focus on the game only but through the game, the basic techniques in martial arts can be well understood by the kohai. However, until now the development of game model training for kenzhi in increasing knowledge and skills to learn the basic techniques of kempo has not been found. 
The relevant theory in this research is the research (Ramadhani \& Purwanto, 2017). The results of this study indicate that the basic Judo technique game model for beginner judos aged 8-12 years consists of 6 game models, able to improve the basic techniques of the judo. The difference in this research lies in the basic technique, subject, place, time, number of subjects, types of martial arts, and the resulting product. The researcher produced five game-based exercise models in the form of a manual. Another difference is that previous researchers only focused on slamming while researchers prioritized hitting, parrying, and kicking techniques.

The importance of this research is to present the method of practicing the basic techniques of traditional game-based kempo martial arts for kenshi beginners. This training method is a new training model in kempo martial arts training with a full approach to traditional games. The purpose of this research is to make it easier for kohai to understand every basic technique of kempo martial arts in a simple, fun way, to increase the spirit of training for beginner kenshi and to present practice theory while playing. Then this research answers the needs that exist in the Special Region of Yogyakarta Perkemi which has 37 dojos (practice places) such as the USD dojo, UGM, UII, UAYO, AMIKOM etc.

Traditional sports and games have an effect on increasing the spirit and motivation of kenshi in exploring various basic techniques found in shorinji kempo martial arts. Therefore, with the training model through this traditional game, it can answer the training needs of basic shorinji kempo martial arts techniques for beginner kenshi (Septiadi, Widiastuti \& Hernawan, 2019). In realizing this, the selection of traditional games will determine the training model that will be produced. This model is different from the previous training model, because this model is based on traditional games, so that trainers can easily transfer kempo martial arts techniques to kenzhi beginners (Nisak, 2011).

\section{METHOD}

This study uses the Research \& Development (R\&D) method (Ingleby, 2012; Filho \& Kovaleva, 2015). The research design used is a preliminary field test in the validation process, the core field test consists of small and large scale tests and then operational field tests (Simonyan \& Zisserman, 2015). The research areas are 5 dojos in DIY, namely Amikom, SDN Wonosari Baru, Triharjo, Balong, and SMPN Panjatan. The small-scale experimental research subjects were 20 beginners kenshi from 2 practice sites, and the large-scale 45 beginners kenshi test from 3 practice sites with a total of 65 beginners kenshi subjects. Methods of collecting data in this study were in the form of observation, interviews, and distributing questionnaires (Taylor et al., 2012; Taylor \& Posch, 2014).

The method of analyzing the data in this study is a qualitative and quantitative MIX data analysis technique where the data analysis method is a procedure to find data systematically and organized through observations, interviews, and field notes, while quantitative data analysis techniques are data obtained from collecting questionnaires to the participants kenshi beginners and trainers (Sheard, 2018). Then the data will be analyzed using SPSS version 25 to get an idea of the training model developed through traditional games.

\section{RESULTS AND DISCUSSION \\ Needs Analysis}

From the results of interviews with 8 Kempo martial arts trainers, the following results were obtained: 1 ). The training methods used in the practice of basic martial arts techniques have been less attractive, this makes the beginner kenshi quickly get bored in practicing, 2). Beginners kenshi want a game method of practicing kempo martial arts techniques, 3). The training method used by the sinpai is still monotonous, 4). There are not many methods of practicing the basic techniques of kempo martial arts through local games. So, with the findings of the problem in the kempo martial arts training model, the researchers wanted to develop a method of training the basic techniques of kempo martial arts through traditional games for beginner kenshi at the perkemi of the Special Region of Yogyakarta.

The initial product list is an initial design to develop a method of training basic kempo martial arts techniques through local games. The list of initial local game products in the basic techniques of kempo 
martial arts consists of five training methods: 1). Gobak Sodor method, 2). Zondag, 3). Yes, 4). Patil catfish, 5). Stick dance.

\section{Product Trial Results Data Expert Test Results}

\begin{tabular}{cccccc}
\hline No & Expert & Minimum Score & Maximum Score & Score Result & Percentage \\
\hline $\mathbf{1}$ & Expert 1 & 0 & 100 & 100 & $100 \%$ \\
$\mathbf{2}$ & Expert 2 & 0 & 100 & 100 & $100 \%$ \\
$\mathbf{3}$ & Expert 3 & 0 & 100 & 100 & $100 \%$ \\
\hline \multicolumn{7}{r}{} \\
\cline { 2 - 3 }
\end{tabular}

From the expert validation results, the draft test is categorized as normal, this is inseparable from the 14 questions given to the three experts with a scale of 5, then the three experts gave an assessment of the initial draft on a scale of 4 and 5 with a percentage of $100 \%$ with appropriate indicators. Furthermore, the results from the three experts are described in table 2 below.

Table 2. Normative Calculation of Conformity Categorization by Experts

\begin{tabular}{ccc}
\hline Formulation & Interval & Category \\
\hline $\mathbf{X}<(\boldsymbol{\mu}+, \mathbf{0 c})$ & $\mathrm{X}<25$ & Less \\
$(\boldsymbol{\mu}-\mathbf{1 , 0 6}) \leq \mathbf{X}<(\boldsymbol{\mu}+\mathbf{1 , 0 6})$ & $25 \leq \mathrm{X}<35$ & Enough \\
$(\boldsymbol{\mu + 1 , 0 ~} \mathbf{6}) \leq \mathbf{x}$ & $35 \leq \mathbf{X}$ & Normal \\
\hline
\end{tabular}

Note:

$\mathrm{x}$ :subject absolute value $\quad \mu$ : ideal mean $\quad \sigma$ : ideal standard deficiency

The results of the calculation of the normative category of conformity to the draft training model through the game can then be seen the distribution of the assessment frequencies of the three experts in the next table, the frequency of small-scale trial assessments is presented.

\section{Small Scale Test}

Validation accruals on a small scale by experts are more dominant on a scale of four and five with a scale of 4 being good and very good so that validation accruals on a small scale are included in the normal category and then presented at $100 \%$ of the ratings given by 3 experts thus small-scale validation according to the method of practicing the basic techniques of kempo martial arts through local games for beginner kenshi. The results of small-scale validation are presented in table three as follows.

Table. 3 Small Group Trial Recap Data

\begin{tabular}{|c|c|c|c|c|c|c|c|c|c|c|c|c|c|c|c|c|}
\hline \multirow{2}{*}{ Game Code } & \multirow{2}{*}{$\begin{array}{c}\text { Expert } \\
\text { Code }\end{array}$} & \multicolumn{14}{|c|}{ Question Number } & \multirow[b]{2}{*}{$\Sigma$} \\
\hline & & 1 & 2 & 3 & 4 & 5 & 6 & 7 & 8 & 9 & 10 & 11 & 12 & 13 & 14 & \\
\hline & & \multicolumn{15}{|c|}{ Assessment Results } \\
\hline \multirow{3}{*}{ P1 } & A1 & 5 & 5 & 5 & 5 & 5 & 5 & 4 & 5 & 4 & 5 & 5 & 5 & 5 & 5 & 68 \\
\hline & $\mathrm{A} 2$ & 5 & 5 & 5 & 5 & 5 & 5 & 4 & 5 & 4 & 5 & 5 & 5 & 5 & 5 & 68 \\
\hline & Sin & 4 & 5 & 5 & 4 & 3 & 3 & 4 & 4 & 4 & 5 & 5 & 5 & 4 & 5 & 60 \\
\hline \multirow{3}{*}{$\mathbf{P 2}$} & A1 & 5 & 5 & 5 & 5 & 5 & 5 & 4 & 5 & 4 & 5 & 5 & 5 & 5 & 5 & 68 \\
\hline & $\mathrm{A} 2$ & 5 & 5 & 5 & 5 & 5 & 5 & 4 & 5 & 4 & 5 & 5 & 5 & 5 & 5 & 68 \\
\hline & Sin & 4 & 5 & 5 & 4 & 3 & 3 & 4 & 4 & 4 & 5 & 5 & 5 & 4 & 5 & 60 \\
\hline \multirow{3}{*}{ P3 } & A1 & 5 & 5 & 5 & 5 & 5 & 5 & 4 & 5 & 4 & 5 & 5 & 5 & 5 & 5 & 68 \\
\hline & $\mathrm{A} 2$ & 5 & 5 & 5 & 5 & 5 & 5 & 4 & 5 & 4 & 5 & 5 & 5 & 5 & 5 & 68 \\
\hline & Sin & 4 & 5 & 5 & 4 & 3 & 3 & 4 & 4 & 4 & 5 & 5 & 5 & 4 & 5 & 60 \\
\hline \multirow{3}{*}{ P4 } & A1 & 5 & 5 & 5 & 5 & 5 & 5 & 4 & 5 & 4 & 5 & 5 & 5 & 5 & 5 & 68 \\
\hline & $\mathrm{A} 2$ & 5 & 5 & 5 & 5 & 5 & 5 & 4 & 5 & 4 & 5 & 5 & 5 & 5 & 5 & 68 \\
\hline & Sin & 4 & 5 & 5 & 4 & 3 & 3 & 4 & 4 & 4 & 5 & 5 & 5 & 4 & 5 & 60 \\
\hline
\end{tabular}




\begin{tabular}{|c|c|c|c|c|c|c|c|c|c|c|c|c|c|c|c|c|}
\hline \multirow{2}{*}{ Game Code } & \multirow{2}{*}{$\begin{array}{c}\text { Expert } \\
\text { Code }\end{array}$} & \multicolumn{15}{|c|}{ Question Number } \\
\hline & & 1 & 2 & 3 & 4 & 5 & 6 & 7 & 8 & 9 & 10 & 11 & 12 & 13 & 14 & $\Sigma$ \\
\hline & & \multicolumn{15}{|c|}{ Assessment Results } \\
\hline \multirow{3}{*}{ P5 } & A1 & 5 & 5 & 5 & 5 & 5 & 5 & 4 & 5 & 4 & 5 & 5 & 5 & 5 & 5 & 68 \\
\hline & A2 & 5 & 5 & 5 & 5 & 5 & 5 & 4 & 5 & 4 & 5 & 5 & 5 & 5 & 5 & 68 \\
\hline & Sin & 4 & 5 & 5 & 4 & 3 & 3 & 4 & 4 & 4 & 5 & 5 & 5 & 4 & 5 & 68 \\
\hline
\end{tabular}

Table 4. Expert Calculations on the Effectiveness of the Practice Method Through Small-Scale Local Games

\begin{tabular}{|c|c|c|c|c|}
\hline Formula & Interval & Category & $\mathbf{F}$ & $\%$ \\
\hline$X<(\mu+06)$ & $X<25$ & Not Appropriate & 0 & 0 \\
\hline$(\mu-1,0 \sigma) \leq x<(\mu+1,0$ б $)$ & $25 \leq X<35$ & Quite Appropriate & 0 & 0 \\
\hline$(\mu+1,0 \sigma) \leq x$ & $35 \leq X$ & Appropriate & 3 & 100 \\
\hline \multicolumn{3}{|c|}{ Amount } & 3 & 100 \\
\hline
\end{tabular}

Note:

$\mathrm{x}$ :subject absolute value $\quad \mu$ : ideal mean $\quad \sigma$ : ideal standard deficiency

Table 3 proves that the average score obtained from the expert lies in the interval $35<x$. The score is included in the effective group based on the assessment of the three experts with $100 \%$ thus the method of practicing martial arts kempo through local wisdom for beginner kenshi is said to be effective because it has gone through various small-scale tests in the form of exercises.

\section{Large-Scale Trial Data}

Test on a large scale is obtained through the items given to 3 experts. Then the data income is processed using a Likert scale below. The presentation of large-scale test data acquisition methods for practicing martial arts kempo through local wisdom for beginner kenshi.

Table 5. The Results of the Validation of the Three Experts on All Methods of Practicing Through Large-Scale Local Wisdom

\begin{tabular}{|c|c|c|c|c|c|c|c|c|c|c|c|c|c|c|c|c|}
\hline \multirow{2}{*}{ Game Code } & \multirow{2}{*}{$\begin{array}{c}\text { Expert } \\
\text { Code }\end{array}$} & \multicolumn{15}{|c|}{ No Item } \\
\hline & & 1 & 2 & 3 & 4 & 5 & 6 & 7 & 8 & 9 & 10 & 11 & 12 & 13 & 14 & $\Sigma$ \\
\hline & & \multicolumn{15}{|c|}{ Evaluation sequel } \\
\hline \multirow{3}{*}{ P1 } & B1 & 5 & 5 & 5 & 5 & 5 & 5 & 4 & 5 & 4 & 5 & 5 & 5 & 5 & 5 & 68 \\
\hline & B2 & 5 & 5 & 5 & 5 & 5 & 5 & 4 & 5 & 4 & 5 & 5 & 5 & 5 & 5 & 68 \\
\hline & $\mathrm{P}$ & 4 & 5 & 5 & 4 & 3 & 3 & 4 & 4 & 4 & 5 & 5 & 5 & 4 & 5 & 60 \\
\hline \multirow{3}{*}{ P2 } & B1 & 5 & 5 & 5 & 5 & 5 & 5 & 4 & 5 & 4 & 5 & 5 & 5 & 5 & 5 & 68 \\
\hline & B2 & 5 & 5 & 5 & 5 & 5 & 5 & 4 & 5 & 4 & 5 & 5 & 5 & 5 & 5 & 68 \\
\hline & $\mathrm{P}$ & 4 & 5 & 5 & 4 & 3 & 3 & 4 & 4 & 4 & 5 & 5 & 5 & 4 & 5 & 60 \\
\hline \multirow{3}{*}{ P3 } & B1 & 5 & 5 & 5 & 5 & 5 & 5 & 4 & 5 & 4 & 5 & 5 & 5 & 5 & 5 & 68 \\
\hline & B2 & 5 & 5 & 5 & 5 & 5 & 5 & 4 & 5 & 4 & 5 & 5 & 5 & 5 & 5 & 68 \\
\hline & $\mathrm{P}$ & 4 & 5 & 5 & 4 & 3 & 3 & 4 & 4 & 4 & 5 & 5 & 5 & 4 & 5 & 60 \\
\hline \multirow{3}{*}{ P4 } & B1 & 5 & 5 & 5 & 5 & 5 & 5 & 4 & 5 & 4 & 5 & 5 & 5 & 5 & 5 & 68 \\
\hline & B2 & 5 & 5 & 5 & 5 & 5 & 5 & 4 & 5 & 4 & 5 & 5 & 5 & 5 & 5 & 68 \\
\hline & $\mathrm{P}$ & 4 & 5 & 5 & 4 & 3 & 3 & 4 & 4 & 4 & 5 & 5 & 5 & 4 & 5 & 60 \\
\hline \multirow{3}{*}{ P5 } & B1 & 5 & 5 & 5 & 5 & 5 & 5 & 4 & 5 & 4 & 5 & 5 & 5 & 5 & 5 & 68 \\
\hline & B2 & 5 & 5 & 5 & 5 & 5 & 5 & 4 & 5 & 4 & 5 & 5 & 5 & 5 & 5 & 68 \\
\hline & $\mathrm{P}$ & 4 & 5 & 5 & 4 & 3 & 3 & 4 & 4 & 4 & 5 & 5 & 5 & 4 & 5 & 68 \\
\hline
\end{tabular}

The results of the large-scale validation test by the three experts on a scale of 5 which were included in the very good category became very many choices and were followed by a scale of 4 which was in the good category of 14 items, thus the large-scale trial was declared normal in the category according to the percentage of $100 \%$. 


\section{Product Effectiveness Test Data}

The effectiveness test was tried with the method of equating the evaluation results at the early meeting to the end of this research after carrying out a production usability test. The subjects in the study were used as illustrations for the test of the effectiveness of the method of practicing basic techniques in kempo martial arts through local wisdom, namely the beginner kenshi at the Balong training ground which were grouped into 2 groups, namely the group using the local wisdom method and the other group not using the local wisdom method, subject 10 beginners kenshi.

The evaluation sequel to the evaluation rubric is then presented in the form of numerical information in the form of a percentage of the average scale on the experimental and control group tests. The results of the information obtained in the trial will be presented below:

\section{Normality Test}

Table 6. Recap of the Initial Test of Normality Test

\begin{tabular}{|c|c|c|}
\hline \multicolumn{3}{|c|}{ One Sampling Kolmogorov Smirnov Test } \\
\hline $\mathrm{N}$ & & 20 \\
\hline \multirow[t]{2}{*}{ Normali Parameter ${ }^{a-b}$} & mean & .000000 \\
\hline & Std.devisiation & 5.11778154 \\
\hline \multirow[t]{3}{*}{ Moste extreme differencese } & Absolute & .131 \\
\hline & Positive & .131 \\
\hline & Negative & -.128 \\
\hline Statistic Test & & .131 \\
\hline Asimp.sig.(w-tailed) & & $.200^{\mathrm{c}, \mathrm{d}}$ \\
\hline
\end{tabular}

a. Distributiont test is normality.

b. Calculated from data

After conducting the normality test, the data in the research method of practicing basic martial arts techniques was declared normally distributed, through the decision-making criteria if $p>0.05$ then the data in this study was declared normal/experiencing an error.

\section{Homogeneity Test}

Table 7. Test of Homogeneity of Variances Homogeneity of Pretest

\begin{tabular}{lcccc}
\hline Levene statistic & Df1 & Df2 & Sig. & \\
\hline 110 & 1 & 8 & 748 & \\
\hline
\end{tabular}

The barometer for making decisions is $\mathrm{P}>0.05$ so it can be concluded that the information found is homogeneous, then vice versa if $\mathrm{P}<0.05$ means that it can be concluded that if the information has farin not homogeneous. Based on statistical studies of similarity tests that have been tried using Levene's test. To get an average significant score of 0.678 .0 .05 so that the information for the initial test and final test in each group is that the data is homogeneous.

\section{Experimental Group Result Count}

Table 8. Summary of Paired Samples Test Scores on the Practice Method Through Traditional Games

\begin{tabular}{lllll}
\hline & Paired Differences & t & df & Sig. (2-tailed) \\
\hline \multirow{3}{*}{$\begin{array}{l}\text { Pair 1 Experimental Preetest - Experimental } \\
\text { Posttest }\end{array}$} & $95 \%$ Confidence Interval of the & & & \\
& Difference & & & \\
\cline { 2 - 6 } & Upper & -17.571 & 9 & .000 \\
\cline { 2 - 6 }
\end{tabular}


In the above calculation using the SPSS version 25 application, the results are then concluded that: 1). A is equal to 0.05 , which is greater than the sig value, so there is no change in the training model developed 2). If $\mathrm{a}=0.05 \mathrm{sig}$ value, there will be a difference or a change in the pre and post giving treatment.

The information in the table above concludes that it has a big impact on increasing the description of practicing methods for the basic techniques of kempo martial arts through local wisdom. The average sig value is 0.05 , this means that there is a very large impact on the results of the pretest and posttest of the experimental group. So the first hypothesis has a very large impact on increasing the description of beginner kenshi, the method of practicing basic techniques of kempo martial arts through local wisdom, is accepted. The significant impact can be seen in table 9 below:

Table 9. Percentage of Initial Test Mean Score

\begin{tabular}{cll}
\hline No & Exercise model name & Initial Test Score Percentage \\
\hline $\mathbf{1}$ & Block & $42.50 \%$ \\
$\mathbf{2}$ & Jump rope & $41.88 \%$ \\
$\mathbf{3}$ & Phatil catfish & $40.00 \%$ \\
$\mathbf{4}$ & Zodag & $31.66 \%$ \\
$\mathbf{5}$ & Bamboo Dance & $30.83 \%$ \\
\hline & Initial Score Percentage & $\mathbf{1 8 6 . 8 7 \% : 5 = 3 7 . 1 7 \%}$ \\
\hline
\end{tabular}

The entire process of testing the effectiveness of the basic technique training model of kempo martial arts through traditional games on kenshi beginners of elementary school age obtained an average total data at the initial meeting of $37.17 \%$.

Table 10. Percentage of Final Mean Score

\begin{tabular}{|c|c|c|}
\hline No & Exercise Model Name & Final mean score \\
\hline 1 & Block & $68.75 \%$ \\
\hline 2 & Jump rope & $86.66 \%$ \\
\hline 3 & Phatil catfish & $70.50 \%$ \\
\hline 4 & Zodag & $50.00 \%$ \\
\hline 5 & Bamboo Dance & $98.75 \%$ \\
\hline \multicolumn{2}{|c|}{ Final Mean Score Percentage } & $374.66 \%: 5=74,93 \%$ \\
\hline
\end{tabular}

The overall effectiveness test on the method of practicing martial arts kempo through local wisdom for elementary school age beginners kenshi obtained a total average data at the final meeting of $74.93 \%$.

\section{Experimental and Control Group Difference Test}

To get a truth, it is necessary to have a test that focuses on the process to get maximum results, in other words, through testing between the experimental group and the control group in knowing the scores of the basic techniques of kempo martial arts training for the kenshi-kenshi using the practice method through traditional games/groups. Experimental and other groups who still use the exercise model that are often used in the dojo or do not use the training method that the researcher developed.

Table 11. Independent Test Different Experimental and Control Test

\begin{tabular}{ccccc}
\hline & \multicolumn{4}{c}{ T - Tes For Equaliti Of Mean } \\
\hline \multirow{2}{*}{$\begin{array}{c}\text { Test the difference between } \\
\text { the experimental and control } \\
\text { groups }\end{array}$} & Equal variance assumed & df & Sig.(2tailed) & Means diferenences \\
\cline { 3 - 5 } & & 18 & .0000 & 12.3000 \\
\hline
\end{tabular}

A research that will certainly produce products in various forms, for example an exercise model or a book that will be used as a reference in various disciplines (Gupta \& Vegelin, 2016; Weststrate et al., 2019). As for the purpose of a study, because a study without a goal then the research has no benefits or is not useful (Sandgren et al., 2020; Strydom, 2013). The purpose of this research is to create an exercise model in traditional game-based shorinji kempo martial arts. The resulting model is based on children aged or 
beginner kenshi. Hopefully this training model will answer the problems faced by beginner kenzhi when practicing various basic techniques of shorinji kempo martial arts.

The research similar to this research is research of (Hariadi, 2016). The results of this study indicate that the basic Karate technique game model for karate athletes uses traditional games, to produce training guidelines for coaches and uses 4 kinds of games. However, previous research has made a training model specifically for Karate trainers as a guide in training karate. So it is different from the findings of researchers who created a model of basic technical training with the main focus being the beginner kenzhi of shorinji kempo. The location of the differences from previous research is the number of research subjects, time, types of self-defense, and basic techniques which are the main focus of previous research, namely: only kicks and punches, while the research includes three basic techniques, namely punches, parries, and kicks.

Five training models are prioritized in this study, namely: Gobak Sodor, Yeye, Pahtil catfish, Zogdag, Stick dance. The model in this study is based on five traditional games that are inherited by the ancestors of the Indonesian nation (Maulida \& Jatmiko, 2019; Saputra, 2017). This training model makes it easy for kenshi to perform various movements based on the basic techniques of shorinji kempo martial arts. So that the child's identity as a world of play is not drained by self-defense training activities (Du et al., 2021; Haiat et al., 2003). The training method is the most important part for an athlete to achieve goals and achievement, Therefore, the training method must be designed as simple as possible so that kenzhi can enjoy training without having to be a burden in achieving the desired achievement (Baker et al., 2019; Saddhono et al., 2018).

Based on the results of the SPSS calculation above, conclusions can be drawn if: 1) If a (sig) $=0.05$ is greater than or equal to the value of sig. or [ $a=0.05 \mathrm{sig}$ ], it means that there is no difference in increase, 2) If $\mathrm{a}=0.05$ is smaller or with a sig value. or $[\mathrm{a}=0.05 \mathrm{sig}]$, there is a significant difference in increase. After taking various tests until the product test, the next test is the analysis prerequisite test, where there is a normality test, homogeneity, then continued with an influence test and a difference test between experiment and control and each test that is passed using the method of practicing martial arts kempo through local wisdom is declared normal or according to the needs of elementary school age beginners kenshi. Then it was concluded that, there was a difference in the improvement in the results of understanding the basic techniques of traditional game-based kempo martial arts between the groups who took part in the training using the traditional game-based kempo martial arts training model and the control group, or groups that were not given any treatment. Based on the significance value of the independent t-test of $0.00<0.05$, which means that it is smaller than the significant level. Then validation test, small scale test, large scale, and product effectiveness test. Then tested again by testing the analytical prerequisites, namely normality test and homogeneity test. And the last is the test of the effect of the experimental group and the difference test between the experimental group and the control group, so each test is declared normal or appropriate.

Tests carried out by experts, both material experts and Sinpai meet the criteria to produce a model of training in the basic techniques of kempo martial arts based on traditional games. This can be seen from the percentage of the initial test value or pretest of all training models is $37.17 \%$. This percentage was obtained when the kohais were not given any treatment, while the posttest percentage was $68.75 \%$, thereby increasing the average value of the kohais by $40.50 \%$. In the group difference test, it is calculated using SPSS. Based on the significance value of independent $t$ - tests of $0.00<0.05$, which means that it is smaller than the significant level. Thus, the result of calculating the normal value does not experience an error (Feng et al., 2014).

\section{CONCLUSION}

Based on the exposure of the research results, it can be concluded as follows: The basic technique training model for kempo martial arts based on the traditional game of kenshi beginners is carried out in 8 stages, namely: 1) field information collection, 2) information analysis that has been collected 3) initial product development (model draft) 4) expert validation and revision 5) trial small scale and revision 6) large scale trial and revision 7) final product manufacture, 8) effectiveness test. The results showed that the exercise model could improve the ability of kenshi in basic movements of kempo martial arts techniques. 
The training model for the basic techniques of kempo martial arts is very suitable and feasible for beginner kenshi because the product of this training model has gone through validation and expert judgment such as material experts and trainers/sinpai kempo martial arts, this can be seen from the results of largescale trial observations. The assessment of the experts showed that the value given was in the interval $35 \mathrm{X}$. This figure was included in the effective category. The four observers (100\%) assessed that the overall traditional game-based training model on a large-scale trial was effective in the training process. Thus, it can be concluded that the basic technique training model of traditional game-based kempo martial arts is appropriate to be used in training the basic techniques of kempo martial arts in kenshi.

The limitations in this study are that the researchers focus on research only on beginner kenshi, the number of subjects is small, the experts/Sinpai involved are still very limited and the practice/dojo is still limited. Therefore, the researcher recommends other prospective researchers to study traditional games in an approach with other disciplines and use professional research subjects in other sports.

\section{ACKNOWLEDGMENT}

Thank you to those who have contributed to this research. In particular thanks to the Kohai, Kenshi, and the Simpai at the dojos in DIY. The researchers also thank Dr. Widiyanto, M. Kes and Prof. Dr. Suharjana M.Kes who always direct researchers to complete this research.

\section{CONFLICT OF INTEREST}

All authors declare there is no conflict of interest in this study. Further research needs to be done. Adding types of traditional games that can be modified into training methods in shorinji kempo martial arts.

\section{REFERENCES}

Baker, J., Schorer, J., Lemez, S., \& Wattie, N. (2019). Understanding high achievement: The case for eminence. Frontiers in Psychology, 6(1), 123-143. https://doi.org/10.3389/fpsyg.2019.01927

Bartkus, K. R., Nemelka, B., Nemelka, M., \& Gardner, P. (2012). Clarifying the meaning of extracurricular activity: A literature review of definitions. American Journal of Business Education (AJBE), 5(6), 694698. https://doi.org/10.19030/ajbe.v5i6.7391

Bowman, P. (2017). The definition of martial arts studies. Martial Arts Studies, 3(6), 12-15. https://doi.org/10.18573/j.2017.10092

Bowman, P. (2021). The Invention of Martial Arts. In The Invention of Martial Arts, 1(3), 272-276. https://doi.org/10.1093/oso/9780197540336.001.0001

Brandão, A. P., \& Lordelo, L. da R. (2017). The meanings of extracurricular activities for ballarinian children. Psicologia Escolar e Educacional, 2(2), 10-13. https://doi.org/10.1590/217535392017021311178

Cynarski, W. J., Pawelec, P., Yu, J.-H., Slopecki, J., Bielec, G., \& Kubala, K. (2018). Young people practicing martial arts and their perception of success. Pedagogics, Psychology, Medical-Biological Problems of Physical Training and Sports,7(3),790-781. https://doi.org/10.15561/18189172.2018.0502

Downey, G. (2014). 'As Real As It Gets!' Producing hyperviolence in mixed martial arts. JOMEC Journal, 14(3), 13-19. https://doi.org/10.1177/ 0306312706072174

Du, Y., Grace, T. D., Jagannath, K., \& Salen-Tekinbas, K. (2021). Connected play in virtual worlds: Communication and control mechanisms in virtual worlds for children and adolescents. Multimodal Technologies and Interaction, 5(5), 27-29. https://doi.org/10.3390/MTI5050027

Feng, C., Wang, H., Lu, N., Chen, T., He, H., Lu, Y., \& Tu, X. M. (2014). Log-transformation and its implications for data analysis. Shanghai Archives of Psychiatry, 26(2), 105-108. https://doi.org/10.3969/j.issn.1002-0829.2014.02 
Filho, W. L., \& Kovaleva, M. (2015). Research methods. In Environmental Science and Engineering (Subseries: Environmental Science), 5(1), 95-103. https://doi.org/10.1007/978-3-319-10906-0_5

Finnegan, E. G., \& Accardo, A. L. (2018). Understanding Character Perspective: Strategies to Support Students With Autism Spectrum Disorder. Reading Teacher, 40(7), 890-892. https://doi.org/10.1002/trtr.1682

Fonagy, P., Gergely, G., Jurist, E. L., \& Target, M. (2018). Affect regulation, mentalization and the development of the self. In Affect Regulation, Mentalization and the Development of the Self, 16(3), 301-305. https://doi.org/10.4324/9780429471643

Guest, A. M. (2018). The social organization of extracurricular activities: Interpreting developmental meanings in contrasting high schools. Qualitative Psychology, 4(2), 285-293. https://doi.org/10.1037/qup0000069

Gupta, J., \& Vegelin, C. (2016). Sustainable development goals and inclusive development. International Environmental Agreements: Politics, Law and Economics, 5(1), 41-58. https://doi.org/10.1007/s10784016-9323-Z

Haiat, H., Bar-Mor, G., \& Shochat, M. (2003). The world of the child: A world of play even in the hospital. Journal of Pediatric Nursing, 18(3), 209-212. https://doi.org/10.1053/jpdn.2003.28

Hanif, A. S. (2016). Falsafah Pengukuran dan Teknik Dasar Shorinji Kempo. Rajawali Pers.

Hariadi. (2016). Pengembangan Model Latihan Gerak Dasar Karate Melalui Modifikasi Permainan Tradisional untuk pemula. UNY Press.

Ingleby, E. (2012). Research methods in education. Professional Development in Education, 38(3), 507509. https://doi.org/10.1080/19415257.2011.643130

Irwan, I., \& Mulyadi, M. (2017). Analisis Medan Makna 'Seni Bela Diri Khas Jepang' Dalam Huruf Kanji $\mathrm{Bu}$ (武). Izumi, 6(2), 31-49. https://doi.org/10.14710/izumi.6.2.31-49

James, L. P., Robertson, S., Haff, G. G., Beckman, E. M., \& Kelly, V. G. (2017). Identifying the performance characteristics of a winning outcome in elite mixed martial arts competition. Journal of Science and Medicine in Sport, 20(3), 296-301. https://doi.org/10.1016/j.jsams

Kamarudin. (2014). Pengaruh Metode Berbeban Terhadap Kecepatan Tendangan Sabit Pada Atlet Pencak Silat Unit Kegiatan Mahasiswa Universitas Islam Riau. Jurnal Primary, 3(2), 79-80. http://dx.doi.org/10.33578/jpfkip.v3i2.2498

Kim, H.-S., Han, D.-I., \& Kwon, O.-R. (2019). Definition for Martial Arts from the Perspective of Taijiquan. The Journal of the Korean Society for the Philosophy of Sport, Dance, \& Mattps:rtial Arts, 13(5), 210-212. https://doi.org/10.31694/pm.2019.03.27.1.006

Kusnierz, C., Cynarski, W. J., \& Gorner, K. (2017). Social reception and understanding of combat sports and martial arts by both school students and adults. Ido Movement for Culture, 17(1), 30-37. https://doi.org/10.14589/ido.17.1.5

Liang, L. M., Zou, C. G., Xu, J., \& Zhang, K. Q. (2019). Signal pathways involved in microbe-nematode interactions provide new insights into the biocontrol of plant-parasitic nematodes. In Philosophical Transactions of the Royal Society B: Biological Sciences, 17(3), 180-183. https://doi.org/10.1098/rstb.2018.0317

Long, J. D. (2012). Unifying Hinduism: Philosophy and Identity in Indian Intellectual History - By Andrew J. Nicholson. Religious Studies Review, 5(4), 262. https://doi.org/10.1111/j.1748-0922.2011.01585_5.x 
Lorge, P. A. (2011). Chinese martial arts: From antiquity to the twenty-first century. In Chinese Martial Arts: From Antiquity to the Twenty-First Century, 11(3), 220-223. https://doi.org/10.1017/CBO9781139029865

Maulida, S. H., \& Jatmiko. (2019). Pembelajaran Matematika Berbasis Etnomatematika Melalui Permainan Tradisional Engklek. UNY Press.

Misaki, S. (2013). The Words Of So Doshin. Kobunsha. Pubns. Inc; 2nd Printing edition

Nisak, R. (2011). Seabrek Games Asyik-Edukatif untuk Mengajar PAUD/TK. Jakarta: Diva Press.

Park, C., \& Kim, T. Y. (2016). Historical views on the origins of Korea's Taekwondo. International Journal of the History of Sport, 33(9), 9-12. https://doi.org/10.1080/09523367.2016.1233867

Petri, K., Bandow, N., Masik, S., \& Witte, K. (2019). Improvement of Early Recognition of Attacks in Karate Kumite Due to Training in Virtual Reality. Journal Sport Area, 4(2), 294-308. https://doi.org/10.25299/sportarea.2019.vol4(2).3370

Ricci, J. M., Clevenger, K. A., Sellers, S., Davenport, S., \& Pfeiffer, K. A. (2020). Associations between extracurricular activity participation and health-related variables in underrepresented children. Sports Medicine and Health Science, 6(1), 102-108. https://doi.org/10.1016/j.smhs.2020.06.001

Saddhono, K., Pitaloka, R. I., Devilito, R., Mulyaningsih, I., Sudarsana, I. K., Isnaniah, S., Istanti, W., \& Septiana, H. (2018). Relationship between effective sentence understanding and achievement motivation with description text writing skill on google classroom. International Journal of Engineering and Technology(UAE), 7(2), 135-137. https://doi.org/10.14419/ijet.v7i2.13.18134

Samuel, G., \& Johnston, J. (2013). Religion and the subtle body in Asia and the West: Between mind and body. In Religion and the Subtle Body in Asia and the West: Between Mind and Body, 5(8), 82-87. https://doi.org/10.4324/9780203558249

Sandgren, E. P., Streiffer, R., Dykema, J., Assad, N., \& Moberg, J. (2020). Attitudes toward animals, and how species and purpose affect animal research justifiability, among undergraduate students and faculty. PLoS ONE, 15(8), 215-219. https://doi.org/10.1371/journal.pone.0233204

Saputra, S. Y. (2017). Permainan Tradisional vs Permainan Modern dalam Penanaman Nilai Karakter di Sekolah Dasar. Elementary School Education Journal), 1(1), 1518. http://dx.doi.org/10.30651/else.v1i1.873

Scheunemann, T. (2012). Kurikulum sepakbola Indonesia Untuk Usia Dini (u15-u12), Usia Muda (u13-u20) $\&$ Senior. Gramedia.

Septiadi, A., Widiastuti., \& Hernawan. (2019). Model latihan speed endurance berbasis senam pencak silat untuk usia remaja. Journal Sport Area, 4(2), 285-293. https://doi.org/10.25299/sportarea.2019.vol4(2).1803

Sheard, J. (2018). Quantitative data analysis. In Research Methods: Information, Systems, and Contexts: Second Edition, 18(2), 227-230. https://doi.org/10.1016/B978-0-08-102220-7.00018-2

Shufelt, C. (2011). Sources: Martial Arts of the World: An Encyclopedia of History and Innovation. Reference \& User Services Quarterly, 51(1), 117-200. https://doi.org/10.5860/rusq.51n1.80.2

So, D (1981). What is Shorinji Kempo. Japan Pubns. Inc; 2nd Printing edition.

Stark, L., \& Landis, D. (2016). Violence against children in humanitarian settings: A literature review of population-based approaches. Social Science and Medicine, 1(52), 125-137. https://doi.org/10.1016/j.socscimed.2016.01.052

Strydom, H. (2013). An evaluation of the purposes of research in social work. Social Work (South Africa), 49(2), 8-11. https://doi.org/10.15270/49-2-58 
Ramadhani, A., \& Purwanto, S. (2017). Pengembangan latihan teknik dasar judo melalui model permainan untuk pejudo pemula usia 8-12 tahun. Jurnal Keolahragaan, 5(1), 1-10. https://doi.org/10.21831/jk.v5i1.12755

Taylor, K. E., Stouffer, R. J., \& Meehl, G. A. (2012). An overview of CMIP5 and the experiment design. In Bulletin of the American Meteorological Society, 11(1), 25-28. https://doi.org/10.1175/BAMS-D-1100094.1

Taylor, S. C., \& Posch, A. (2014). The design of a quantitative western blot experiment. In BioMed Research International, 30(4), 560-563. https://doi.org/10.1155/2014/361590

Wali, C. N., \& Widiyanto. (2020). Peningkatan Gerak Geri Komi Melalui Gaya Melatih Secara Otoriter Dalam Bela Diri Kempo Dojo Persatuan Guru 1945 Kupang. Jurnal Penelitian dan Pengembangan Pendidikan,3(2), 115-125.

Weststrate, J., Dijkstra, G., Eshuis, J., Gianoli, A., \& Rusca, M. (2019). The Sustainable Development Goal on Water and Sanitation: Learning from the Millennium Development Goals. Social Indicators Research, 3(1), 20-23. https://doi.org/10.1007/s11205-018-1965-5

Wetzler, S. (2015). Martial arts studies as Kulturwissenschaft: A possible theoretical framework. Martial Arts Studies, 6(2), 10-13. https://doi.org/10.18573/j.2015.10016

Xu, C., Li, Q., Qu, X., Chen, J., \& Zhou, A. (2020). Ant-hemipteran association decreases parasitism of Phenacoccus solenopsis by endoparasitoid Aenasius bambawalei. Ecological Entomology, 12(4), 290292. https://doi.org/10.1111/een.12797

Yates, R. D. S. (2015). Chinese Martial Arts from Antiquity to the Twenty-first Century, written by Peter A. Lorge. Journal of Chinese Military History, 4(7), 675-679. https://doi.org/10.1163/2212745312341291

Züst, T., Heichinger, C., Grossniklaus, U., Harrington, R., Kliebenstein, D. J., \& Turnbull, L. A. (2012). Natural enemies drive geographic variation in plant defenses. Science, 338(6103), 116-119. https://doi.org/10.1126/science.1226397 